University of Michigan Law School

University of Michigan Law School Scholarship Repository

\title{
Introduction: International Law Governing Armed Conflict
}

\author{
Christian Marxsen
}

\author{
Anne Peters \\ University of Michigan Law School, anneps@umich.edu
}

Available at: https://repository.law.umich.edu/book_chapters/156

Follow this and additional works at: https://repository.law.umich.edu/book_chapters

Part of the Human Rights Law Commons, International Humanitarian Law Commons, and the Organizations Law Commons

\section{Publication Information \& Recommended Citation}

"Introduction: International Law Governing Armed Conflict." Co-authored by Christian Marxsen. In Law Applicable to Armed Conflict, edited by Ziv Bohrer, Janina Dill, and Helen Duffy, 1-14. Max Planck Trialogues on the Law of Peace and War, 2. Cambridge: Cambridge University Press, 2020.

This Book Chapter is brought to you for free and open access by the Faculty Scholarship at University of Michigan Law School Scholarship Repository. It has been accepted for inclusion in Book Chapters by an authorized administrator of University of Michigan Law School Scholarship Repository. For more information, please contact mlaw.repository@umich.edu. 


\title{
Introduction: International Law Governing Armed Conflict
}

\author{
Christian Marxsen and Anne Peters
}

Wars are emergency situations, but in contrast to the saying that necessity knows no law, they are not lawless situations at all. Quite to the contrary, an extensive body of international treaties and customary international law provides detailed regulations. However, which rules do and should apply to what kinds of situation is a hotly debated issue and the subject of this book. Different regulatory paradigms are competing for how wartime situations shall be regulated - with significant legal, practical and institutional implications.

This book approaches the legal issue in a Trialogue. The characteristic feature of a Trialogue is to approach questions of international law from three perspectives, which differ in terms of their regional background, technical method, professional specialisation and worldview of the co-authors. The three authors (who are embedded in their particular social and cultural context) approach the law from their particular perspective, which invariably influences what they identify as the relevant rules and how they interpret and apply those. The core method of the 'Max Planck Trialogues on the Law of Peace and War' is to positively acknowledge the diversity of perspectives and to make constructive use of them (multi-perspectivism). The direct meeting of divergent views should expose that and how the political as well as regional factors and accompanying intellectual styles influence the scholarly approach taken and the legal answers given. By inviting the participants of the Trialogues to a conversation and by explicitly focusing on their divergence and disagreement (or their complementarity and synergies), a decentring of perspectives might be facilitated. This should ultimately contribute to a richer understanding of the legal question. ${ }^{1}$

1 See on the methodology of the Trialogues: Anne Peters, 'Trialogical International Law Introduction to the Series', in Mary Ellen O'Connell, Christian Tams and Dire Tladi, 


\section{THE APPLICATION OF INTERNATIONAL HUMANITARIAN LAW}

The classical legal regime applied to wartime situations is international humanitarian law (IHL). IHL pursues a double function. It aims to 'license' State action in armed conflicts, and it aims to regulate or restrain it. ${ }^{2}$ Under the licensing function, acts that would be illegal under peacetime law are legalised. For example, combatants in international armed conflicts enjoy immunity for their acts and are therefore exempt from criminal prosecution for the killing of other combatants during armed conflict (as long as they have complied with applicable rules of IHL concerning the means and methods of warfare). ${ }^{3}$ On the other hand, IHL has a regulating function: it outlaws certain methods of warfare and obliges belligerent parties and fighters to observe certain principles, such as the principle of distinction and proportionality. ${ }^{4}$ In doing so, IHL aims to reconcile two opposing objectives. On the one hand, it seeks to secure military effectiveness by acknowledging a legal principle of military necessity. ${ }^{5}$ However, if this were the sole principle to govern armed conflict, belligerents would be free to take any effective measure for winning a war - with disastrous normative consequences. Accordingly, IHL limits belligerents' choices based on counterprinciples flowing from humanitarian considerations. The entire body of law thereby takes a 'middle road' between these opposing principles. ${ }^{6}$

The concrete rules governing armed conflicts under IHL significantly depend on the type of conflict at hand. International armed conflicts (IACs) are densely regulated by a range of international treaties. While the Hague

Self-Defence against Non-State Actors - Max Planck Trialogues on the Law of Peace and War: Vol. I (Cambridge University Press, 2019), xi-xxv.

2 Jens David Ohlin, The Assault on International Law (Oxford University Press, 2015), 171; Geoffrey S. Corn, 'Mixing Apples and Hand Grenades: The Logical Limit of Applying Human Rights Norms to Armed Conflict', Journal of International Humanitarian Legal Studies 1 (2010), 52-94 (56).

3 See, for example, Art. 43(2) Protocol Additional to the Geneva Conventions of 12 August 1949, and relating to the Protection of Victims of International Armed Conflicts, Geneva, 8 June 1977, 1125 UNTS 3 (hereinafter: API), which stipulates that 'Members of the armed forces of a Party to a conflict... have the right to participate directly in hostilities.'

4 The term 'fighters' is used here to designate combatants as well as members of non-State armed groups.

5 The principle of military necessity allows belligerents 'to apply any amount and kind of force to compel the complete submission of the enemy with the least possible expenditure of time, life, and money.' Nuremberg Military Tribunals, The Hostage Case, Opinion and Judgment of the Military Tribunal V, 19 February 1948, Trials of War Criminals before the Nuremberg Military Tribunals (Washington DC: US Government Printing Office, 1950), 1253.

6 Yoram Dinstein, 'Military Necessity', in Rüdiger Wolfrum (ed.), Max Planck Encyclopedia of Public International Law (online edn.), September 2015, para. 2. 
Conventions I-XIV of 1907 contain detailed rules on the conduct of hostilities, the Geneva Conventions I-IV of 1949 and Additional Protocol I (API), set out rules relating to the protection of persons not participating in hostilities. The 1949 Geneva Conventions apply to all cases of declared war, armed conflict, and military occupation. ${ }^{7}$ Moreover, IACs are also regulated by a significant number of rules of customary international law.

Non-international armed conflicts (NIACs), by contrast, are only sparsely regulated by treaty law. Common Article 3 of the 1949 Geneva Conventions contains some basic rules. A more detailed framework is provided by Additional Protocol II (APII). ${ }^{8}$ A significant legal evolution has taken place in customary international law so that today a range of rules for IACs also applies to NIACs. ${ }^{9}$ Nevertheless, the application of IHL to NIACs is fraught with more legal uncertainty, for example, with regard to the identification of parties. Furthermore, there is not one single legal regime of NIACs. APII applies only when certain conditions (degree of organisation, territorial nexus and the like) are met, whereas the threshold of application of Common Article 3 of the four Geneva Conventions is lower. ${ }^{10}$

Debates on IHL are overshadowed by the perception of a crisis that is fuelled by the difficulties (and partly unwillingness) to apply the existing rules to the current realities of armed conflict. First, many discussants highlight the important role of non-State actors in contemporary armed conflicts and contrast this to a more or less imaginary historical past of State armies fighting against State armies. However, in empirical terms it is not clear whether non-State actors are in fact

7 See Common Art. 2 Convention (I) for the Amelioration of the Condition of the Wounded and Sick in Armed Forces in the Field, Geneva, 12 August 1949, 75 UNTS 31; Convention (II) for the Amelioration of the Wounded, Sick and Shipwrecked Members of Armed Forces at Sea, Geneva, 12 August 1949, 75 UNTS 85; Convention (III) relative to the Treatment of Prisoners of War, Geneva, 12 August 1949, 75 UNTS 135; Convention (IV) relative to the Protection of Civilian Persons in Time of War, Geneva, 12 August 1949, 75 UNTS 287.

8 Protocol Additional to the Geneva Conventions of 12 August 1949, and relating to the protection of victims of non-international armed conflicts, Geneva, 8 June 1977, 1125 UNTS 6o9.

9 See ICTY, Prosecutor v. Dusko Tadić, Case No. IT-94-1, Decision on the defence motion for interlocutory appeal on jurisdiction, 2 October 1995, paras. 119-27. See on the customary rules paralleling the codified rules of API Jean-Marie Henckaerts and Louise Doswald-Beck (eds.), Customary International Humanitarian Law, vol. I (Cambridge University Press, 2004), xxix.

10 Common Art. 3 of the 1949 Geneva Conventions applies to 'armed conflict not of an international character occurring in the territory of one of the High Contracting Parties', whereas Art. 1 APII requires an armed conflict 'which take[s] place in the territory of a High Contracting Party between its armed forces and dissident armed forces or other organized armed groups which, under responsible command, exercise such control over a part of its territory as to enable them to carry out sustained and concerted military operations and to implement this Protocol.' 
more relevant today than in bygone armed conflicts. Ziv Bohrer offers a strong argument that actually not much has changed. ${ }^{11}$ Still, it is widely believed that the rise of non-State actors challenges the established and elaborated IAC framework and thus renders more prominent the legal framework governing NIACs, which is at the same time blurrier due to the significance of customary international law for these conflicts.

The (perceived) rise of non-State actors has, secondly, posed problems for applying the established legal framework; ${ }^{12} \mathrm{Ziv}$ Bohrer speaks of a felt 'classification crisis. ${ }^{13}$ We witness widespread uncertainty about the applicable legal frameworks, especially where conflicts internationalise, i.e., where States intervene in NIACs. ${ }^{14}$

A related phenomenon is, thirdly, that the boundaries of armed conflict are perceived to be unclear. What are the limits of armed conflicts, especially in geographical and temporal terms? ${ }^{15}$ The idea of a potentially global armed conflict against non-State actors such as terrorist groups - in itself problematic - has brought 'gray zone conflicts' ${ }^{16}$ into the debate's focus in which the wartime/peacetime divide is apparently blurred.

This situation is, fourthly, worsened by the fact that the institutional framework of IHL remains weak. In fact, effective institutions securing better compliance with IHL are lacking, ${ }^{17}$ and even though especially international criminal tribunals have contributed significantly to the clarification of IHL, no specific IHL-related judicial bodies exist.

Fifthly, IHL faces a normative challenge. Its licensing function under which States may liberate themselves from the constraints of peacetime law is regarded by many to be normatively unsatisfactory. The licensing of certain

11 Bohrer in this volume, 109 et seq.

12 See Duffy in this volume, $17-18$.

13 Bohrer in this volume, 109 .

14 See on the dispute and on the different legal positions Dapo Akande, 'Classification of Armed Conflicts: Relevant Legal Concepts', in Elizabeth Wilmshurst (ed.), International Law and the Classification of Conflicts (Oxford University Press, 2012), 32-79 (56-64); see generally Kubo Mačák, Internationalized Armed Conflicts in International Law (Oxford University Press, 2018).

15 See on this point especially Duffy in this volume, 22-54. See further Claus Kreß, 'Some Reflections on the International Legal Framework Governing Transnational Armed Conflicts', Journal of Conflict and Security Law 15 (2010), 245-74 (264-7).

16 Asbjørn Eide, Allan Rosas and Theodor Meron, 'Combating Lawlessness in Gray Zone Conflicts Through Minimum Humanitarian Standards', American Journal of International Law 89 (1995), 215-23 (215).

17 See on recent initiatives aiming to establish mechanisms that could enhance States' compliance with IHL Jelena Pejic, 'Strengthening Compliance with IHL: The ICRC-Swiss Initiative', International Review of the Red Cross 98 (2016), 315-30. 
types of violence may be seen to conflict with the objective of effectively protecting the individual, which is increasingly considered to be the actual telos of international law. ${ }^{18}$

\section{THE EMERGENCE AND INFLUENCE OF HUMAN RIGHTS}

While IHL has always been driven by a tension between the principle of military necessity, on the one hand, and humanitarian considerations, on the other, the latter became more prominent after the Second World War. In the post-1949 period we witness what Theodor Meron has described as the humanization of humanitarian law'. ${ }^{19}$ This 'great transformation'20 is characterised by a growing emphasis put on the protection of individuals: the 1949 Geneva Conventions focus on protecting persons not participating in hostilities, and their Common Article 3 contains a 'mini-human-rights treaty'. ${ }^{21}$ The 1977 Additional Protocols further instilled human rights ideals into IHL. ${ }^{22}$ Moreover, human rights considerations have more concretely influenced the interpretation of the rules of IHL. $^{23}$ The International Criminal Tribunal for the former Yugoslavia (ICTY) has made 'recourse to instruments and practices developed in the field of human rights law', ${ }^{24}$ and explained that '[w]ith regard to certain of its aspects, international humanitarian law can be said to have fused with human rights law' ${ }^{25}$ Along this line, the ICTY has, for

18 See generally Anne Peters, Beyond Human Rights - The Legal Status of the Individual in International Law (Cambridge University Press, 2016).

19 Theodor Meron, 'The Humanization of Humanitarian Law', American Journal of International Law 94 (2000), 239-78 (239).

$2 \circ$ David Luban, 'Human Rights Thinking and the Laws of War', in Jens David Ohlin (ed.), Theoretical Boundaries of Armed Conflict and Human Rights (Cambridge University Press, 2016), $45-77$ (6o).

21 Ibid.

22 API did so, for example, by establishing a prohibition of reprisals against the civilian population (see Art. 51(6)). APII creates an extensive framework for the protection of victims of NIACs. See generally Gabriella Blum, 'The Fog of Victory', European Journal of International Law 24 (2013), 391-421 (404).

23 For example, the definition of protected persons under Geneva Convention IV has changed. The clear wording of Art. 4 covers only persons who 'find themselves, in case of a conflict or occupation, in the hands of a Party to the conflict or Occupying Power of which they are not nationals'. Nevertheless, the ICTY found that also persons holding the nationality of the controlling party or of the occupying power may be protected under certain circumstances (ICTY, Prosecutor v. Tadić, Case No. IT-94-1-A, Judgment of 15 July 1999, para. 169).

24 ICTY, Prosecutor v. Kunarac et al., Case Nos IT-96-23-T and IT-96-23/1-T, Judgment of 22 February 2001, para. 467.

25 Ibid., para. 467, adding, of course, 'that notions developed in the field of human rights can be transposed in international humanitarian law only if they take into consideration the specificities of the latter body of law' (ibid., para. 471). 
example, relied on international human rights law (IHRL) ${ }^{26}$ to define the concept of torture within IHL. ${ }^{27}$ Thus, IHRL is partly drawn on as the normative background system providing interpretive guidance. ${ }^{28}$ Helen Duffy, in this book, provides a detailed analysis of this process of interpretative adaptation. $^{29}$

In addition to the more indirect effect of human rights law for the interpretation of IHL rules, the relevant actors have in the last decades begun to directly apply human rights law to armed conflict situations. ${ }^{30}$ "[T] here has been', as Geoffrey S. Corn put it, 'a steady march of human rights application into an area formerly subject exclusively to the law of armed conflict.'31

Such direct application of human rights law hinges on two legal premises. First, in the majority of conflicts where one State operates outside its territory, a legal precondition for the application of human rights to these actions is that they can also apply outside the State's territory. ${ }^{32}$ Although such extraterritorial applicability is today acknowledged as a matter of principle, details remain complicated. ${ }^{33} \mathrm{Also}$, the human rights treaties' clauses on derogations on which States might rely in situations of armed conflict differ. ${ }^{34}$ Therefore, the extent of obligations arising under those human rights treaties remains the subject of controversy.

26 This abbreviation will be used throughout the book, although it is not common outside the specific debate on the application of human rights law in armed conflict.

27 ICTY, Prosecutor v. Furundžija, Case No. IT-95-17/1, Judgment of 10 December 1998, para. 159 .

28 Brian Orend speaks of 'filling the Law-of-War gap with human rights values', Brian Orend, 'The Next Geneva Convention - Filling a Law-of-War Gap with Human Rights Values', in Jens David Ohlin (ed.), Theoretical Boundaries of Armed Conflict and Human Rights (Cambridge University Press, 2016), 363-97 (363).

29 Duffy in this volume, 71 et seq.

30 See for the view that IHRL and IHL were two completely distinct bodies of law and that thus human rights did not apply in armed conflict, Henri Meyrowitz, 'Le droit de la guerre et les droits de l'homme', Revue du droit public et de la science politique en France et à l'étranger 88 (1972), 1059-105 (1076-7); Keith Suter, 'An Enquiry into the Meaning of the Phrase of Human Rights in Armed Conflicts', Revue de droit pénal militaire et de droit de la guerre 15 (1976), 393-439 (421-2).

31 Corn, 'Mixing Apples and Hand Grenades' 2010 (n. 2), 56.

32 See the human rights treaties' differing clauses on their territorial scope: Art. 2(1) International Covenant on Civil and Political Rights, 19 December 1966, 999 UNTS 171; Art. 1 American Convention on Human Rights, 22 November 1969, 1144 UNTS 123; Art. 1 [European] Convention for the Protection of Human Rights and Fundamental Freedoms, 4 November 1950, 213 UNTS 222.

33 See Duffy in this volume, 71-83. See further Marko Milanovic, Extraterritorial Application of Human Rights Treaties: Law, Principles, and Policy (Oxford University Press, 2011), 209-22; Karen da Costa, The Extraterritorial Application of Selected Human Rights Treaties (Leiden: Martinus Nijhoff, 2013), 301-3.

34 See Art. 4 ICCPR; Art. 5(1) ECHR; Art. 27 ACHR. 
The second premise is that human rights law applies at all to armed conflict situations. Such application has, since the 1960s, been advocated in and by the United Nations, in particular by the UN General Assembly, but the issue remained contentious for decades. ${ }^{35}$ The way for the general acceptance of the application of IHRL to armed conflict situations was ultimately paved by the International Court of Justice. In its Nuclear Weapons Advisory Opinion, the Court found that the International Covenant on Civil and Political Rights (ICCPR) continues to apply during armed conflicts. ${ }^{36}$ This was confirmed in the Wall Advisory Opinion and reaffirmed in the Armed Activities case. ${ }^{37}$ Since then, the tide has shifted, and today the applicability of IHRL to armed conflict situations is, in principle, widely accepted. However, this consensus does not provide answers to the question of how IHL and IHRL law interact or which one prevails in cases of substantive divergence. ${ }^{3}$

\section{A CLASH OF PARADIGMS?}

Human rights have emerged as a competing, or at least as an additional, paradigm for regulating armed conflict-related situations. But although IHL as well as IHRL both aim to protect human beings, the typical scenarios for which both regimes were created are quite different. Human rights law has historically been designed as the general peacetime law. It therefore creates a 'law enforcement framework'39 or 'law and order' paradigm. ${ }^{40}$ IHL, by

35 See the Final Act of the International Conference on Human Rights, Teheran, 22 April to 13 May 1968, UN Doc. A/Conf.32/41, 18; GA Res. 2444 (XXIII) of 19 December 1968; GA Res. 2675 (XXV) of 9 December 1970.

$3^{6}$ ICJ, Legality of the Threat or Use of Nuclear Weapons, Advisory Opinion, ICJ Reports 1996, 226, 240 (para. 25). Marko Milanovic has traced the emergence of the 'lex specialis' principle in regard to the relationship between IHL and IHRL and found that it was largely introduced by the ICJ and could only hardly be found before the ICJ issued its opinion, Marko Milanovic, 'The Lost Origins of Lex Specialis: Rethinking the Relationship between HR and IHL', in Jens David Ohlin (ed.), Theoretical Boundaries of Armed Conflict and Human Rights (Cambridge University Press, 2016), 78-118 (82-103).

37 ICJ, Legal Consequences of the Construction of a Wall in the Occupied Palestinian Territory, Advisory Opinion, ICJ Reports 2004, 136, 178 (para. 106); ICJ, Armed Activities on the Territory of the Congo (Democratic Republic of the Congo v. Uganda), Judgment, ICJ Reports 2005, 168, 242-3 (para. 216).

$3^{8}$ See Andrew Clapham, 'Human Rights in Armed Conflict: Metaphors, Maxims, and the Move to Interoperability', Human Rights and International Legal Discourse 12 (2018), 9-22 (19).

39 See Kenneth Watkin, Fighting at the Legal Boundaries: Controlling the Use of Force in Contemporary Conflict (Oxford University Press, 2016), 449.

$4 \circ$ See Yuval Shany, 'Human Rights and Humanitarian Law as Competing Legal Paradigms for Fighting Terror', in Orna Ben-Naftali (ed.), International Humanitarian Law and International Human Rights Law (Oxford University Press, 2011), 13-33 (14-24). 
contrast, is meant to govern 'situations of massive violence employed by collectives, often under conditions of considerable uncertainty (i.e. "the fog of war") and resource constraints'. ${ }^{41}$

The distinct original fields and environments of application of the two bodies of law (IHL and IHRL) have led to quite different regulatory approaches. ${ }^{42}$ IHL relies largely on a system of obligations, as Ziv Bohrer highlights. ${ }^{43}$ Whether and to what extent IHL also creates individual rights is subject of controversy. ${ }^{44}$ IHL establishes rules of conduct for fighters, and the entire body of law takes into account the situation of those who have to make decisions in wartime situations. IHRL, by contrast, establishes individual rights, requires a rigorous analysis of rights that might potentially be affected and, thus, overall pays more attention to those potentially affected by armed conflict, not to those fighting the conflict.

The pros and cons of each normative framework for armed conflicts have been discussed in international legal scholarship at length. IHL is generally seen to be more in line with the necessities of wartime situations. It reduces complexities (for example, by declaring all enemy fighters to be legitimate targets) and gives military commanders significant discretion. The main objection against IHL results from this body of law's readiness to sacrifice individual rights for the sake of military benefits.

It is therefore often asserted that IHRL might do the better job in protecting individuals in wartime situations. The focus of the body of IHRL on individuals at first sight supports such an assumption. However, it remains disputed whether and under what conditions such protection really works. Sceptics point out that there is a significant gap between 'the legal debate at the strategic level and the reality facing military commanders on the ground'. 45 This gap results from IHRL's tendency to individualise situations and to analyse individual rights violations. Such individualisation can be in conflict with the group-based violence in

41 Ibid., 28-9.

$4^{2}$ Laura Olson, 'Practical Challenges of Implementing the Complementarity between International Humanitarian and Human Rights Law - Demonstrated by the Procedural Regulation of Internment in Non-International Armed Conflict', Case Western Reserve Journal of International Law 40 (2009), 437-61 (450).

43 Bohrer in this volume, 175 et seq.

44 Contrast, for example, Kate Parlett, The Individual in the International Legal System (Cambridge University Press, 2012), 225, stating that IHL 'remains consistent with the nineteenth-century framework of the international legal system, as a system which creates only interstate rights'; and Peters, Beyond Human Rights 2016 (n. 18), 194-201, who argues that IHL may create rights also for individuals.

45 Watkin, Fighting at the Legal Boundaries 2016 (n. 39), 152. 
armed conflict which makes it difficult to take into account individual actors and to engage in a comprehensive analysis of potentially affected rights. ${ }^{46}$ Moreover, rights will often conflict and demand different courses of action that need to be reconciled. Where numerous individuals are involved as fighters and civilians, each situation would need to be assessed, and multiple rights - including those of the fighters that are contemplating action - have to be taken into account. In complex situations of armed conflict, this seems to create excessive demands for fighters and commanders in real-life situations. The challenge against IHRL in armed conflict is therefore that of a 'problematic normative overreaching'.47 IHRL is regarded as too complex, ultimately allowing 'second-guessing of a soldier's decision to use force, thereby weakening the protection of combatant immunity'..$^{8}$ Overall, many regard IHRL to 'impose unrealistic obligations on states'. ${ }^{49}$ A possible consequence is that, in the long run, States could be less inclined to apply the law..$^{\circ}$

This Trialogue teases out highly nuanced assessments of the pros and cons of the application of IHRL to armed conflict situations. Helen Duffy explores how human rights law can and has been interpreted in conflict situations through decades of jurisprudence. Duffy argues that the co-application of IHL and IHRL is beneficial from a legal, policy, victim-oriented and institutional perspective. Janina Dill, by contrast, conceptualises why and when the application of IHRL results in the said normative overreach. Her key argument is that IHRL provides better protection in situations of lower intensity where such overreach can be avoided. However, where intensity increases (as conflicts become 'protracted'51) IHL becomes the better legal framework..$^{2}$ Ziv Bohrer's appraisal is more radical. He argues that the application of human rights to situations of armed conflict

$4^{6} \quad$ Ibid., $55^{6}$.

47 Shany, 'Human Rights and Humanitarian Law as Competing Legal Paradigms' 2011 (n. 40), 29. Luban, 'Human Rights Thinking and the Laws of War' 2016 (n. 20), 67-70, speaks of 'overextending human rights thinking'.

$4^{8}$ Michelle A. Hansen, 'Preventing the Emasculation of Warfare: Halting the Expansion of Human Rights Law into Armed Conflict', Military Law Review 194 (2007), 1-65 (55).

49 Claire Landais and Léa Bass, 'Reconciling the Rules of International Humanitarian Law with the Rules of European Human Rights Law', International Review of the Red Cross 97 (2015), 1295-311 (1296).

50 Françoise Hampson, 'Direct Participation in Hostilities and the Interoperability of the Law of Armed Conflict and Human Rights Law', International Law Studies 87 (2011), 187-213 (192): 'If some rules are perceived to be unrealistic, this is likely to lessen respect for those rules that can be applied in practice.'

${ }_{51}$ 'Protracted' is not mainly a temporal extension but denotes a degree of intensity (ICTY, Tadić, Decision on jurisdiction (n. 9), para. 70).

52 See Dill in this volume, esp. 257-63. 
generally diminishes individual protection, because the entire logic of a rightsbased legal regime results in weakened safeguards for the individual if compared with the protection offered by the obligation-based system of IHL.

Broader concerns against the application of human rights to wartime situations relate to the potential effects for human rights law outside armed conflict. Concessions to the necessities of armed conflict situations under human rights law might, in the end, backfire. ${ }^{53}$ They might undermine the protection afforded by human rights in peacetime because, as Heike Krieger stresses, the concessions might 'spread so that gradually the idea that the state might lawfully kill innocent civilians for security reasons becomes part of human rights law'. ${ }^{54}$

\section{THREE VOICES IN A TRIALOGUE}

Despite extensive studies, the law applicable to armed conflict remains controversial and contestable on various levels. First, the possibility of applying IHRL in an armed conflict as a matter of principle has been acknowledged only recently. Arguably, this legal development is not yet firm and can therefore quickly become the subject of dispute again. This is all the more likely as the centrality of the human being and the concomitant 'humanisation' of IHL might be drawn into question in the course of renewed statism and a shift of values in the international legal order away from the Western tradition. Secondly, many concrete legal questions, for example how to operationalise the potential interplay of IHRL and IHL, are not yet resolved. The crux of diverging standards and resulting norm conflicts persist. Law-appliers need very concrete tools to resolve them in a fair and predicable way, and such tools are still in the making only. Finally, some popular narratives about the law applicable to armed conflict - such as depicting the rise of non-State actors as a recent phenomenon and new challenge - might fall apart when more thoroughly analysed. The debunking of the myth may have consequences for our assessment of what the law is and what it should be. Against this background, the book aims to identify the current state of the law and, at the same time, to challenge some prevailing positions. This book both traces the black-letter debates and focuses on the normative questions that are the driving force behind many of the debates, including the doctrinal ones.

53 Jean-Marie Henckaerts and Ellen Nohle, 'Concurrent Application of International Humanitarian Law and International Human Rights Law Revisited', Human Rights and International Legal Discourse 12 (2018), 23-43 (35).

54 Heike Krieger, 'A Conflict of Norms: The Relationship between Humanitarian Law and Human Rights Law in the ICRC Customary Law Study', Journal of Conflict and Security Law 11 (2006), 265-91 (291). 
The Trialogue (re-)raises three main questions. First, it asks where, when and to whom IHL and IHRL as the relevant bodies of law apply in armed conflict situations. Secondly, it explores the interrelation of IHL and IHRL and the legal techniques for coordinating the two regimes and for preventing or at least mitigating potential norm conflicts. State practice and human rights litigation before international courts are confronted with these norm conflicts, and the emerging and still changing techniques of coordination and underlying principles need to be identified and conceptualised.

Thirdly, and most importantly, this Trialogue moves beyond the positive analysis of the law as it stands and probes the normative principles that guide, or should be guiding, the interpretation, application and development of law applicable to armed conflict. At this juncture, the Trialogue method is expected to furnish most added value. In view of the indeterminacy of the norms at hand and the fuzziness of their interplay, such normative orientation seems particularly important. ${ }^{55}$ For this Trialogue's question of 'applicability' of norms not only the familiar ambiguity and vagueness of the language, but additionally the uncertainty about the principles and techniques of coordination in fact grant interpreters and law-appliers plenty of freedom to bring to bear their own normative convictions. As it is well known, these convictions are not external to applying the law, but provide the background, the Vorverständnis, against which the meaning of the norms is constructed and their interaction designed. Put differently (and this is a truism), normative choices are not alien to the process of applying the law, but rather form its constitutive part. Specifically with regard to the application of international law in armed conflict, Marko Milanovic has observed: 'One can solemnly intone that one is applying the law as it is, the lex lata, not as it should be, but the reality is that the law - particularly this kind of law cannot be divorced from its political context and normative preferences. ${ }^{56}$ The Trialogue specifically seeks to engage in this normative discourse which is a steady undercurrent to the practical and theoretical debates on the law applicable to armed conflict, and it does so through its multiperspectivism.

55 Cf. for the problem of indeterminacy and legal interpretation Christian Marxsen and Anne Peters, 'Conclusion: Self-defence against Non-State Actors - The Way Ahead', in O'Connell, Tams and Tladi (n. 1), 258-81 (264-9).

${ }_{56}$ Marko Milanovic, 'Accounting for the Complexity of the Law Applicable to Modern Armed Conflicts', in Winston S. Williams and Christopher M. Ford (eds.), Complex Battlespaces: The Law of Armed Conflict and the Dynamics of Modern Warfare (Oxford University Press, 2019), 33-6o (38). 
The perspectives of the three co-authors differ in terms of their regional background, technical method, professional specialisation and worldview. Helen Duffy was invited to the Trialogue as a distinguished expert both on human rights law and on IHL who is an academic and at the same time deeply rooted in practice. She is Professor of International Humanitarian Law and Human Rights at Leiden University (the Netherlands), and also runs 'Human Rights in Practice', an international legal practice that provides legal advice and representation in strategic human rights litigation before international, regional and domestic courts. In her chapter, Duffy introduces the complexities of the application of IHL and IHRL to armed conflict situations, hereby providing an answer to the first question posed above. While explaining the settled state of the law in relation to material, personal and temporal dimensions of the applicability of IHL and IHRL, Duffy also shows where the law is unclear and where legal developments are currently underway. Analysing international adjudication and practice, Duffy investigates how the tide has shifted from separating IHL and IHRL as two distinct regimes to their co-application in situations of armed conflict. Duffy's normative vision for the interrelation between IHL and IHRL is embodied in her framework of coapplicability. Within this framework, IHL and IHRL shall, as far as possible, be interpreted in a harmonious way. For cases in which applicable norms conflict in particular contexts, Duffy proposes specific mechanisms of co-application of both legal regimes.

The second Trialogue co-author is Ziv Bohrer, assistant professor at BarIlan University (Israel). Bohrer is an expert on IHL. His past work includes both articles that research current IHL and papers that uncover IHL history. In his present contribution, he combines these two lines of research and employs a historical and critical approach to the question of which legal regimes do and should apply to armed conflict. He first addresses the above-mentioned classification crisis, that is, the apparent incapability of IHL to deal with new forms of conflict in which non-State actors play a significant role. Bohrer rejects the crisis narrative and shows that these developments are, in fact, not new. He traces the debates of IHL and shows that complaints about the blurring of the wartime/peacetime divide, the demise of classical inter-State conflicts which are fought out in battles, or the talk of unprecedented wars that cannot be addressed within the existing legal framework of IHL, have been present since the nineteenth century. According to Bohrer, the occasionally perceived inability of IHL to deal with the realities of contemporary conflict results inter alia from a misconception which he explains as 'temporocentrism', the attitude 
that exaggerates the relevance of most recent developments. ${ }^{57}$ In contrast to such crisis narratives, Bohrer asserts that IHL is highly capable of dealing with current challenges. He points out that IHL comprises all legal tools to adapt to new developments and challenges. Bohrer suggests espousing an 'adaptation approach', acknowledging that IHL rules can be strengthened and complemented with the help of already existing principles of IHL.

Bohrer points out that the actual crises of the law governing armed conflict results from the 'jurisdictional struggle' between IHL and IHRL. He rejects the strategy, advocated, inter alia, by Helen Duffy, of co-applying IHL and IHRL. According to him, the 'righting of IHL' with its shift from an obligation-based to a rights-based system in the regulation of armed conflicts comes with significant dangers. ${ }^{58}$ In contrast to such a 'righting' of IHL, Bohrer asks us to rely more on the internal logic of IHL and to use the adaptation approach in order to make IHL fit to face current challenges. This would avoid abandoning the inherent logic of IHL, especially its obligation-based character, which Bohrer finds to be the better system to guide military operations.

The third Trialogue co-author is Janina Dill. Dill is Associate Professor at the Department of Politics and International Relations at the University of Oxford (UK). Janina Dill was invited to the Trialogue for her background in political theory and expertise on the international regulation and normative dynamics of armed conflicts. Dill approaches the topic of legal regulation of armed conflict situations not as a question of black-letter law, but rather as a moral question. As a starting point, she argues that the law regulating armed conflict has two moral tasks. The first task is to guide soldiers 'towards the course of action that conforms to their moral obligations', 59 that is, it should guide soldiers to direct their fire 'only against individuals who have forfeited their individual moral right to life, ${ }^{60}$ or against individuals whose harming can be justified as a lesser moral evil. The second task, according to Dill, does not relate to the moral obligations of the individual combatant or fighter, but asks for the moral desirability of the outcome of their conduct on the battlefield. Specifically, law should 'avoid and reduce as much as possible all morally unjustified infringements (i.e., violations) of individual rights in war'. ${ }^{61}$ Dill shows that, because IHRL more closely reflects fundamental moral principles about the permissibility of individual rights infringements,

\footnotetext{
Bohrer in this volume, 134 .

Ibid., 173 et seq.

9 Dill in this volume, 198.

6o Ibid., 199.

61 Ibid.
} 
it provides 'the prima facie morally better law for governing hostilities'. ${ }^{62}$ However, Dill identifies a turning point. Where armed conflicts become protracted, ${ }^{63}$ epistemic barriers make it difficult to realise the standards provided for by IHRL, and volitional defects make it unlikely that soldiers will attempt to live up to these standards. While IHRL remains the better law for reminding soldiers of their moral obligations, it nevertheless leads to morally undesirable outcomes during protracted hostilities. Dill therefore argues that, from a moral point of view, IHRL should be the standard legal regime to guide armed conflict situations, but where such conflicts become 'protracted' (i.e., during all NIACs and during protracted IACs), IHL should displace IHRL and become the applicable legal framework.

In their interplay, overlap and partial disagreement, the three voices in this Trialogue not only provide a comprehensive account of the current state of the law, of its trajectory, and of hidden inconsistencies. Moreover, through a nuanced critique of the law and its underlying premises, the contributions invite us to an open engagement with the law's normative undercurrents that inform and influence positions taken on the substance of the law, but are nevertheless often neglected in the debate.

62 Dill in this volume, 200.

63 See for the term supra, n. 51 . 